\title{
종양용해증후군
}

\author{
김혜리 \\ 울산대학교 의과대학 소아청소년과학교실
}

\section{Tumor lysis syndrome}

\author{
Hyery Kim \\ Department of Pediatrics, University of Ulsan College of Medicine, Seoul, Korea
}

Tumor lysis syndrome (TLS) is an oncologic emergency due to the rapid lysis of tumor cells and subsequent release of large amounts of intracellular potassium, phosphate, and uric acid into the bloodstream. Precipitation of uric acid and/or calcium phosphate crystals in the renal tubules can result in acute kidney injury. TLS is frequently observed in children with malignancy, which has high tumor burden, rapid cell turnover or high chemosensitivity (particularly, Burkitt's lymphoma and acute lymphoblastic leukemia), following the initiation of cytotoxic therapy. The current recommendations for prophylaxis and management are based on the TLS risk stratification. It is essential to administer adequate fluid and hypouricemic agents (allopurinol and/or rasburicase) to prevent acute kidney injury. In children susceptible to TLS, prompt diagnosis and aggressive treatment, such as renal replacement therapy, should be performed through close monitoring.

Key words: Acute Kidney Injury; Child; Hyperkalemia; Hyperphosphatemia; Hyperuricemia; Hypocalcemia; Monitoring, Physiologic; Prevention, Primary; Tumor Lysis Syndrome

\section{서 론}

종양용해증후군은 항암제 투여 직후 종양세포의 급격한 파괴로 인해, 세포내 요산, 칼륨, 인이 혈류로 유리되어 발 생한다. 이 증후군은 적절히 치료하지 않으면, 급성신부전 (신부전), 부정맥, 발작, 급사를 초래할 수 있다 ${ }^{1)}$. 요산 배 설이 현저히 증가하면 콩팥요세관(요세관)에 요산 결정이 침전되고, 이로 인해 요세관이 폐쇄되어 신부전이 유발된 다(Fig. 1) $)^{1)}$. 고인산혈증도 신부전에 기여하는데, 요산과

Received: Dec 13, 2016

Revised: Dec 16, 2016

Accepted: Dec 16, 2016

\section{Corresponding author Hyery Kim}

Department of Pediatrics, University of Ulsan College of Medicine, 88 Olympic-ro 43-gil, Songpa-gu, Seoul 05505, Korea

Tel: +82-2-3010-3386 Fax: +82-2-473-3725

E-mail: tabandahanmail.net
인산칼슘은 침전을 상호 촉진한다. 종양용해증후군은 화 학요법 시작 후 24-48시간 이내에, 특히 화학요법에 높 은 감수성을 보이는 버킷림프종 또는 급성림프모구백혈병 에서 자주 발생한다. 종양용해증후군 환자는 대사이상으 로 인해 상태가 빠르게 악화할 수 있어, 적절한 예방요법, 조속한 진단, 적극적인 치료가 중요하다.

\section{본 론}

\section{1. 진단}

종양용해증후군은 대사이상만 나타나는 검사상 종양용 해증후군(laboratory tumor lysis syndrome, LTLS) 과, 여기에 임상증상을 동반한 임상적 종양용해증후군 (clinical TLS, CTLS)으로 분류된다. LTLS는 화학요법 시작 3 일 전부터 7 일 후까지, 요산> $8 \mathrm{mg} / \mathrm{dL}$, 칼륨> 6 


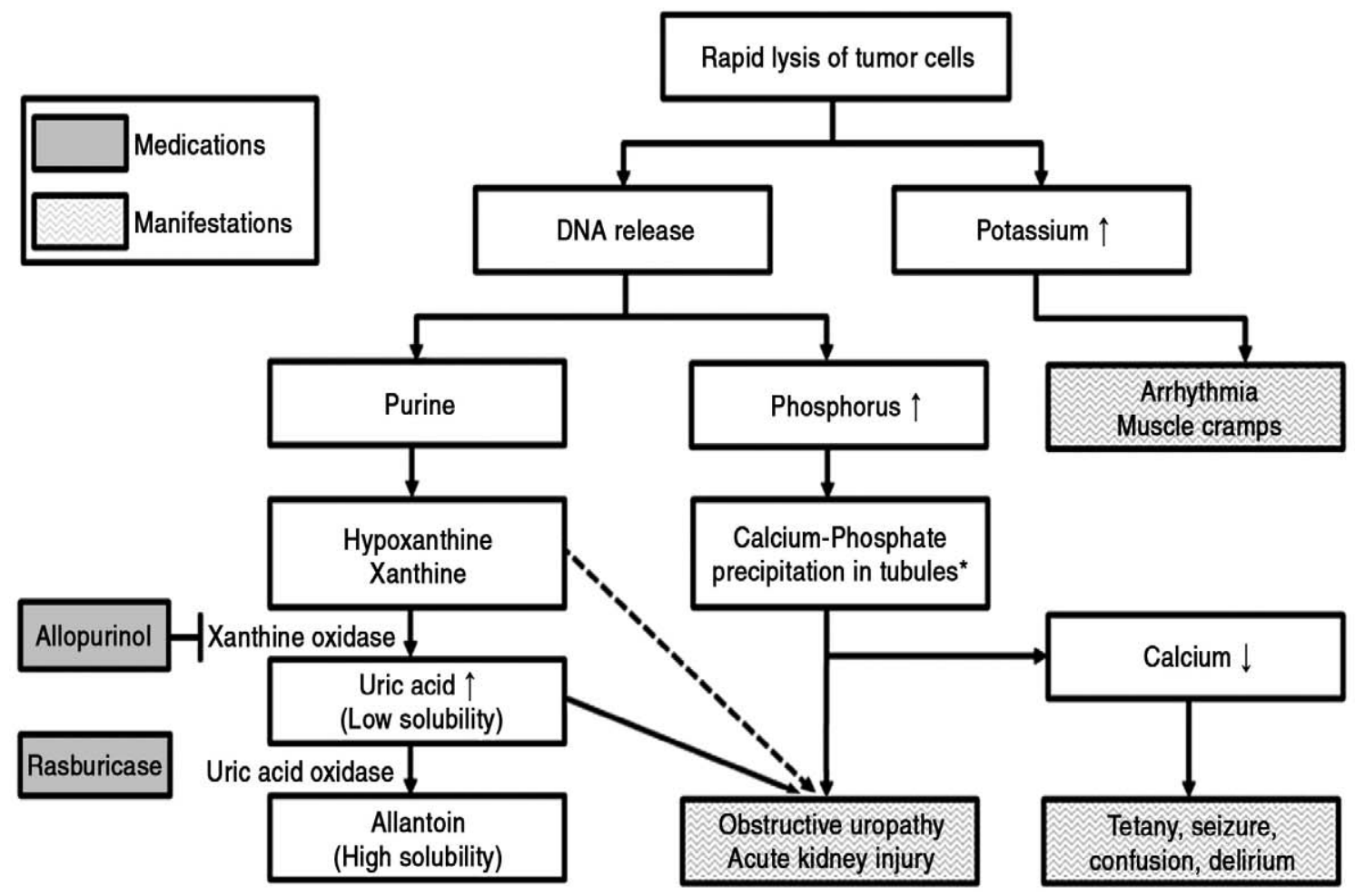

Fig. 1. Pathophysiology of tumor lysis syndrome and pathway of purine catabolism. Allopurinol (xanthine oxidase inhibitor) inhibits formation of uric acid, and rasburicase (recombinant uric acid oxidase) converts uric acid to allantoin, a highly soluble form. It is important to note that obstructive uropathy is caused by precipitation of uric acid, calcium phosphate, and occasionally hypoxanthine or xanthine in the renal tubules, resulting in acute kidney injury.

* Tubules refer to the renal tubules.

$\mathrm{mg} / \mathrm{dL}$, 인산 $>6.5 \mathrm{mg} / \mathrm{dL}$ (성인, > $4.5 \mathrm{mg} / \mathrm{dL}$ ) 또는 칼슘 $<7 \mathrm{mg} / \mathrm{dL}$ 중 두 개 이상을 만족하면 또는 상기 검 사결과가 $25 \%$ 이상 증가(단, 칼슘은 감소)하면 진단된다 ${ }^{1,2)}$. CTLS는 LTLS에 한 개 이상의 임상증상(신부전, 부정맥, 발작, 급사)을 동반하면 진단된다.

급성골수세포백혈병 환자 772 명을 대상으로 한 후향적 연구에 따르면, LTLS와 CTLS는 각각 $12 \%$ 와 $5 \%$ 에서 발 생했다 ${ }^{3)}$. 이 연구에서 종양용해증후군 환자는 사망(주로 출혈 및 신부전)과 신부전의 발생 빈도가 높았고, 이 차이 는 CTLS에서 더욱 현저했다.

\section{2. 예방}

고위험군 환자에서 예방요법을 하면서 종양용해증후군 발생 여부를 감시하는 것이 중요하다(Table 1,2$)^{3,4)}$. 예방 에는 적절한 수액요법과 allopurinol 또는 rasburicase 의 투여가 필요하다. 수액요법의 목적은 신장 관류와 사구 체여과율을 증가시킴으로써 요산과 인산칼슘의 요세관 침 전을 최소화하는 것이다. 다만 용적과부하의 위험을 고려
하여, 수액요법 중 활력징후와 소변량을 감시해야 하며 수 혈은 최소량으로 천천히 시행해야 한다. 만일 폐쇄요로병 과 같은 신부전의 가역적인 원인이 있다면, 수액요법 시작 전에 이를 교정해야 한다.

수액요법은 화학요법 시작 1 일 전부터 $2-3 \mathrm{~L} / \mathrm{m}^{2} /$ day ( $\leq 10 \mathrm{~kg}, 200 \mathrm{~mL} / \mathrm{kg} / \mathrm{day})$ 의 속도로 시행할 것을 권장 한다 ${ }^{2)}$. 소변량은 $80-100 \mathrm{~mL} / \mathrm{m}^{2} / \mathrm{hr}(2 \mathrm{~mL} / \mathrm{kg} / \mathrm{hr}$; $\leq$ $10 \mathrm{~kg}, 4-6 \mathrm{~mL} / \mathrm{kg} / \mathrm{hr}$ ) 이상을 유지하도록 감시한다. 소 변량을 유지하기 위해 이뇨제를 투여할 수 있으나, 혈량저 하 또는 폐쇄요로병을 동반하면 금기이다. 종양용해증후 군에서 일차선택 이뇨제는 알려지지 않았으나, 칼륨을 함 께 배설시키는 고리작용이뇨제가 선호된다.

수액 조성에는 환자 상태가 중요하다. 일반적으로 5\% 포도당에 생리식염수의 $0.25 \%$ 조성으로 투여하는 것을 권장한달. 특히 초기에 스테로이드를 투여하는 화학요법 의 경우(급성림프모구백혈병), 나트륨 정체와 고혈압의 위 험 때문에 저장성 용액을 투여해야 한다. 단, 저나트륨혈 증 또는 혈량저하 시에는 등장성 용액을 투여할 수 있다. 고칼륨혈증과 고인산혈증의 위험 때문에, 칼륨과 칼슘은 
Table 1. Risk stratification of tumor lysis syndrome

\begin{tabular}{lccc}
\hline & & Risk group & \\
\cline { 2 - 4 } & Low & Intermediate & High \\
\hline NHL & Indolent NHL & DLBCL & Burkitt's, lymphoblastic \\
ALL, WBC & $\leq 50,000 / \mathrm{m}^{3}$ & $50,000-100,000 / \mathrm{m}^{3}$ & $\geq 100,000 / \mathrm{m}^{3}$ \\
AML, WBC & $\leq 10,000 / \mathrm{m}^{3}$ & $10,000-50,000 / \mathrm{m}^{3}$ & $\geq 50,000 / \mathrm{m}^{3}$ \\
Other malignancies & $\mathrm{UA}<7.5 \mathrm{mg} / \mathrm{dL}$ & Elevated LDH & $\mathrm{UA} \geq 7.5 \mathrm{mg} / \mathrm{dL}$ \\
& & High tumor burden, rapid & Preexisting renal \\
& & cell turnover or high & insufficiency \\
& & chemosensitivity &
\end{tabular}

NHL: non-Hodgkin's lymphoma, ALL: acute lymphoblastic leukemia, WBC: white blood cell, AML: acute myeloid leukemia, UA: uric acid, DLBCL: diffuse large B-cell lymphoma, LDH: lactate dehydrogenase.

Table 2. Prophylaxis and management based on the tumor lysis syndrome risk stratification

\begin{tabular}{lc}
\hline Risk group & Prophylaxis and management \\
\hline Low & Close monitoring, hydration \\
Intermediate & Close monitoring, hydration, and allopurinol \pm rasburicase* \\
High & Close monitoring, hydration, and rasburicase* ${ }^{+}$ \\
\hline
\end{tabular}

* Contraindicated in children with glucoe-6-phosphate dehydrogenase deficiency.

${ }^{\dagger}$ Consider repeat administration based on the initial response.

Table 3. Management of hyperleukocytosis* and prophylaxis recommendations of tumor lysis syndrome

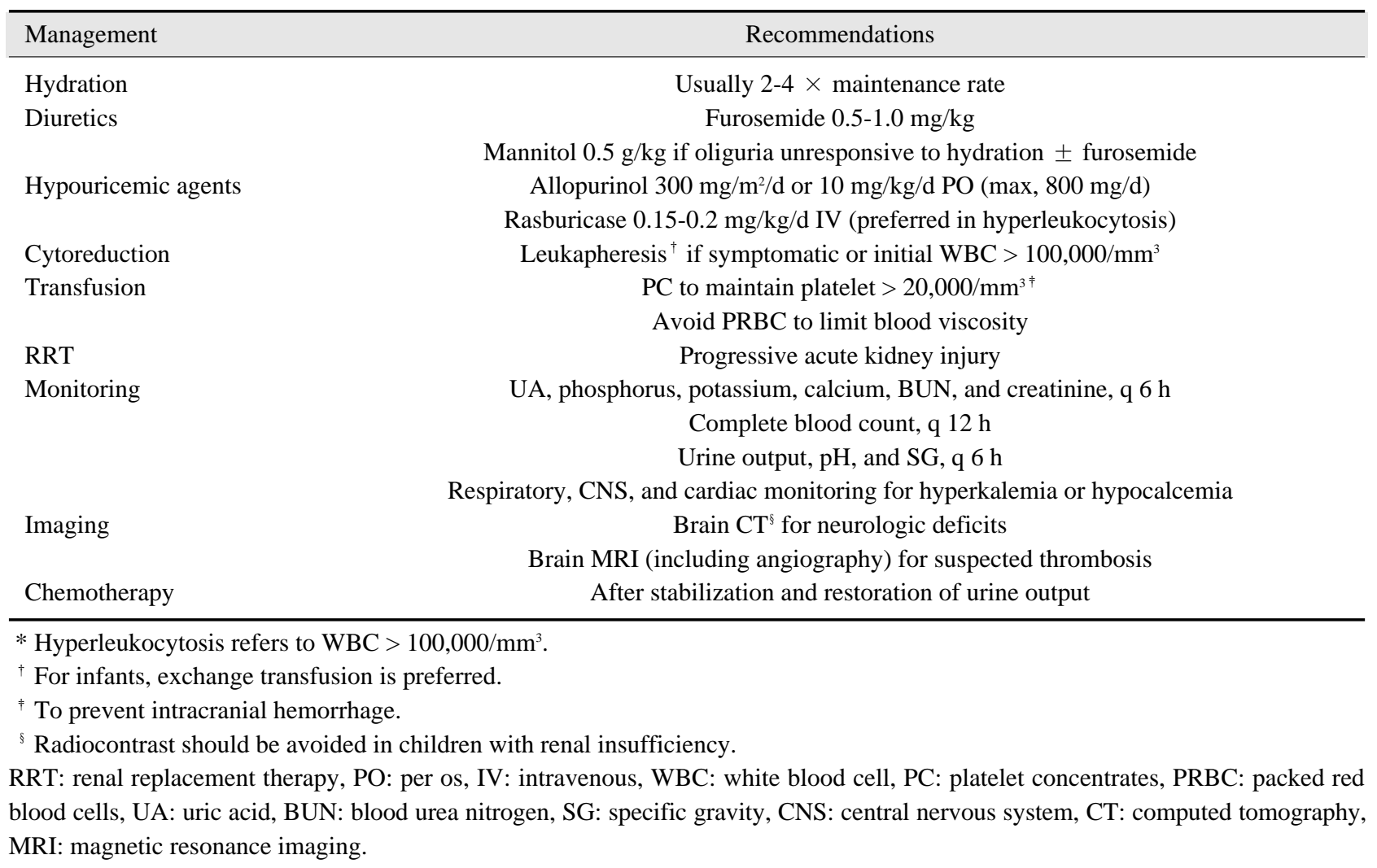


꼭 필요할 때에만 투여한다. 수액요법의 지속기간은, 종양 부하(tumor burden), 항암제, 신기능에 따라 달라질 수 있다. 특히, 급성백혈병에서는 말초모세포수, 간비장비대, 젖산탈수소효소 농도, 종괴 크기 등의 감소 여부를 감시해 야 한다.

기존에는 요산의 용해도를 증가시키기 위해 중탄산염나 트륨을 이용한 소변알칼리화(urine alkalinization, 소 변 $\mathrm{pH}$ 를 6.5-7.5로 유지)를 시행했다.5. 그러나 최근, 소 변알칼리화가 인산칼슘의 용해도를 감소시키고 xanthine 또는 hypoxanthine의 용해도를 증가시키지 않는다는 점 이 확인되어, 더는 권장되지 않는다. 특히, rasburicase 를 투여할 때, 시행하면 안 된다. 따라서 중탄산염나트륨 은 대사산증이 심할 때만 투여해야 한다2).

수액요법 외에도, xanthine과 hypoxanthine이 요산 으로 변환되는 것을 차단하는 allopurinol을 예방적으로 투여한다(Fig. 1). Allopurinol은 요산 자체를 제거하지 는 못하지만, 요산 형성을 감소시킴으로써 요세관 침전을 방지한다. Allopurinol의 부작용에는, 과민반응과 폐쇄요 로병(xanthine 또는 hypoxanthine 침전에 따른)이 있 다. 고위험군에서는 rasburicase를 예방적으로 투여할 수 있다(Table 2). 그러나, 2016년 현재 한국에서는 예방 적인 allopurinol 투여에도 불구하고 종양용해증후군에 따른 고요산혈증이 발생하거나, 화학요법에 따른 구역과 구토가 심하여 allopurinol을 경구투여할 수 없을 때만, 요양급여가 인정된다.

종양용해증후군이 의심되면, 투여된 수액량과 소변량을 감시해야 한다. 또한, 반복적인 혈액검사(요산, 전해질, 혈 액요소질소, 크레아티닌, 젖산탈수소효소)가 필요한데, 고 위험군은 예방요법 시작 후 4-6시간마다, 중간위험군은 8-12시간마다 시행한다.1). 고위험군에서는 지속적인 심전 도 감시가 추가로 필요하다. Hyperleukocytosis를 동반 한 급성백혈병은 고위험군에 해당하므로, 특별한 주의가 필요하다(Table 3).

\section{3. 치료}

예방요법에도 불구하고, $3 \%-5 \%$ 에서는 종양용해증후군 이 발생할 수 있다. 또한, 일부 비호지킨림프종 또는 급성 림프모구백혈병 환자에서는 화학요법 시작 전에도 종양용 해증후군이 발생할 수 있다. 일단 진단되면, 심전도를 포 함한 집중감시와 반복적인 혈액검사(4-6시간마다)가 필요 하다. 치료는 예방요법에 준한 수액요법, allopurinol 또 는 rasburicase 투여, 대사이상 교정으로 이루어진다. 예 방과 마찬가지로 위험군에 따른 접근이 필요하다(Table
1, 2). 신부전이 빠르게 진행할 수 있으므로, 신대체요법 을 조기에 고려하는 것이 좋다.

\section{1) 고요산혈증}

고요산혈증(요산 $>8 \mathrm{mg} / \mathrm{dL}$ )은 종양용해증후군에서 가 장 흔한 대사이상이다. 고요산혈증은 푸린이 요산으로 분 해되어 유발된다(Fig. 1). 요산이 요세관에 침전되어 사구 체여과율이 감소하고, 궁극적으로 신부전으로 진행한다.

Allopurinol의 예방적 투여는 대부분 화학요법 시작 1-2일 전부터 시작하고, 요산 농도가 안정되는 시작 3-7 일 후까지 지속할 수 있다. Allopurinol의 용량은 50$100 \mathrm{mg} / \mathrm{m}^{2}$ (경구, 8시간마다, 최대 $300 \mathrm{mg} / \mathrm{m}^{2} /$ day)이 다(성인, $100 \mathrm{mg} / \mathrm{m}^{2}$, 최대 $800 \mathrm{mg} /$ day). 신부전이 진 행하면 allopurinol과 그 대사물이 침전될 수 있으므로, 용량을 $50 \%$ 까지 줄일 수 있다. 투여 시, 다른 약물(시클로 포스파미드, 벤다무스틴, 고용량 메토트렉세이트, 암피실 린, 아목시실린, 카르바마제핀, 고리작용이뇨제, 티아지드 등)과의 상호작용 가능성을 주의해야 한다 ${ }^{6)}$. 또한, 혈관염 과 스티븐스-존슨증후군 등의 부작용을 유발할 수 있다.

Allopurinol 외에 rasburicase를 투여할 수 있다. Rasburicase는 요산을 알란토인으로 전환하는데, 알란토 인은 요산보다 약 5-10배 강한 용해도를 가진다(Fig. 1) Rasburicase는 allopurinol과 달리 1회 투여 4시간 이 내에 효과적으로 요산 농도를 낮출 수 있어, 투여 4시간 후 요산 농도를 측정하고 이후 6-12시간마다 반복 측정하 며 상황에 따라 반복 투여할 수 있다 ${ }^{8}$. Rasburicase의 용 량은 $0.15-0.2 \mathrm{mg} / \mathrm{kg}$ (정맥내, 요산 $\leq 7.5 \mathrm{mg} / \mathrm{dL}$, $0.15 \mathrm{mg} / \mathrm{kg}$; 요산> $7.5 \mathrm{mg} / \mathrm{dL}, 0.2 \mathrm{mg} / \mathrm{kg}$ )이다. 투 여 후 요산 농도가 충분히 감소했다면, allopurinol을 재 투여할 수 있다.

Rasburicase와 allopurinol의 효능을 비교한 3 개 임 상연구에 대한 체계적 문헌고찰에 따르면, rasburicase 군에서 투여 4 시간 후 요산 농도가 정상화되는 빈도가 높 았다.9. 소아 환자 52 명을 대상으로 한 무작위대조시험에 서도, rasburicase 군에서 투여 4시간 후 요산 농도의 감 소 폭이 더욱 컸다 ${ }^{8}$. 다만, 사망과 신부전의 빈도는 유의 한 차이를 보이진 않았다.

Rasburicase는 glucoe-6-phosphate dehydrogenase 결핍증 환자에서 메트헤모글로빈혈증과 용혈빈혈을 유발 할 수 있어 금기이며, 일부에서 아나필락시스가 보고되어 주의해야 한다 ${ }^{10,11}$.

\section{2) 고칼륨혈증}

고칼륨혈증(칼륨 > $6 \mathrm{mg} / \mathrm{dL}$ )은 종양세포 파괴로 인해 
세포내 칼륨이 다량 유리되어 발생한다. 고칼륨혈증은 부 정맥 또는 급사를 유발할 수 있어, 종양용해증후군에서는 칼륨 함유 수액은 금기이다. 칼륨 농도가 정상 범위보다 약간 증가 $(5.5-6.0 \mathrm{mEq} / \mathrm{L})$ 했지만 증상이 없다면, 심전 도를 감시하며 관찰할 수 있다. 이때 sodium polystyrene sulfonate $(1 \mathrm{~g} / \mathrm{kg}, 6$ 시간마다)를 투여할 수 있다. 고칼 륨혈증이 발생하면, 속효인슐린 $(0.1 \mathrm{U} / \mathrm{kg} / \mathrm{hr})$ 과 포도당 $(0.5 \mathrm{~g} / \mathrm{kg} / \mathrm{hr})$ 을 동시에 투여한다. 응급상황에서는 중심 정맥으로 $50 \%$ 포도당 $(1 \mathrm{~mL} / \mathrm{kg})$ 을 투여할 수 있다. 인슐 린 투여 후 면밀한 혈당감시가 필요하다. 중탄산염나트륨 (1-2 mEq/kg)을 정맥내투여하면, $\mathrm{pH}$ 가 0.1 상승할 때 마다 칼륨은 $1 \mathrm{mEq} / \mathrm{L}$ 씩 감소할 수 있고, 투여 30 분 이 내에 효과가 나타나 수 시간 동안 지속한다. 이외에도, 중 탄산염나트륨은 심근과민성과 대사산증을 완화하는 효과 가 있다. 심각한 부정맥이 발생하면, 심전도를 감시하면서 $10 \%$ 글루콘산칼슘 $(100-200 \mathrm{mg} / \mathrm{kg}$ )을 정맥내투여(30분 에 걸쳐)한다. 칼슘 정맥내투여 시, 중탄산염나트륨과 같 은 정맥주사선을 사용하는 것은 금기이다. 지속적인 고칼 륨혈증은 추가로 신대체요법이 필요하다.

\section{3) 고인산혈증}

고인산혈증(인산 > $6.5 \mathrm{mg} / \mathrm{dL}$; 성인, > $4.5 \mathrm{mg} / \mathrm{dL}$ )은 세포내 인산이 다량 유리되어 발생한다. 종양세포의 세포 내 인산 함유량은 정상세포의 4 배이다. 고인산혈증에서는 수산화알루미늄 $(150 \mathrm{mg} / \mathrm{kg} / \mathrm{day}, 6$ 시간마다)을 경구투 여한다. 이를 통해 인의 흡수는 억제되지만, 농도를 감소 시키진 못한다. 고칼슘혈증을 동반하지 않으면, 탄산칼슘 (44-65 mg/kg/day, 6시간마다)을 투여할 수 있다. 수액 요법 또한, 소변량을 $3 \mathrm{~mL} / \mathrm{kg} / \mathrm{hr}$ 이상으로 유지하도록 충분히 시행한다. 그러나, 고인산혈증이 지속하면 인산칼 슘 침전을 예방하기 위해 신대체요법을 고려해야 한다.

\section{4) 저칼슘혈증}

저칼슘혈증(칼슘 $<7 \mathrm{mg} / \mathrm{dL}$; 이온화 칼슘 기준, $<1.12$ $\mathrm{mg} / \mathrm{dL}$ )은 인산칼슘 침전으로 인해 이차적으로 발생한다. 인산칼슘 침전은 폐쇄요로병으로 인한 신부전을 초래할 수 있다. 테타니 등 저칼슘혈증의 임상증상이 발생하면, $10 \%$ 글루콘산칼슘 $(50-100 \mathrm{mg} / \mathrm{kg})$ 을 정맥내투여한다. 투여 시 심전도 감시가 필요하고, 인산칼슘 침전을 예방하 기 위해 가급적 조기에 중단해야 한다. 고인산혈증이 지속 하면 신대체요법을 고려해야 한다.

\section{5) 고칼슘혈증}

고칼슘혈증은 암 환자에서 종양으로 인한 이차현상, 뼈 용해, 부동화, 요배설 이상 등으로 인해 발생할 수 있다. 칼슘 농도가 $12 \mathrm{mg} / \mathrm{dL}$ 이상이면, 오심, 구토, 변비, 쇠 약, 가려움, 뼈통증, 다음, 다뇨, 신장기원 요붕증, 서맥, 탈수, 신부전, 파종혈관내응고 등이 나타날 수 있다.

치료를 위해, 탈수와 대사이상을 교정하고 칼슘 함유 약 제를 중단한다. 특히 생리식염수로 수액요법(유지용량의 $2-3$ 배)을 충분히 시행함으로써 칼슘의 요배설을 촉진한 다. 그리고 퓨로세마이드 $(1-2 \mathrm{mg} / \mathrm{kg}, 6$ 시간마다)를 반복 투여하고, 뼈에서 칼슘 유리를 막기 위해 비스포스폰산염 (pamidronate, zoledronate)을 투여할 수 있다. 림프세 포증식질환에서는 프레드니솔론 $(1.5-2.0 \mathrm{mg} / \mathrm{kg})$ 을 매일 투여하는 것이 도움이 된다.

\section{6) 신부전}

신부전은 주로 요산, 인산칼슘, hypoxanthine 또는 xanthine (특히, 소변 $\mathrm{pH} \geq 7.5$ 또는 allopurinol 투여 시)의 침전으로 인해 유발되고 ${ }^{12)}$, 그 밖에 신장의 혈관수축 과 관류저하, 사이토카인에 따른 전신염증반응증후군을 통해 유발되기도 한다 ${ }^{11}$. 종양용해증후군에서 신대체요법 의 적응증(Table 4)은 다른 원인의 신부전 시와 유사하지

Table 4. Indications for renal replacement therapy in tumor lysis syndrome

\begin{tabular}{l}
\hline Indications \\
\hline Presence of hyperphosphatemia and hypercalcemia \\
An estimated glomerular filtration rate $<50 \%$ \\
Volume overload unresponsive to diuretic therapy \\
Anuria and overt uremic symptoms* \\
Persistent hyperkalemia with QRS widening and/or $\left[\mathrm{K}^{+}\right]>6 \mathrm{mEq} / \mathrm{L}$ \\
Congestive heart failure \\
Severe symptomatic hypocalcemia \\
Severe metabolic acidosis \\
* Uremic symptoms refer to various manifestations related to uremia, including but not limited to, encephalopathy, pericarditis, and \\
neuropathy.
\end{tabular}


만, 칼륨 농도가 급격하게 상승할 수 있으므로 조기에 시 행해야 한담. 혈역학적으로 불안정하면 지속적 신대체요 법(continuous renal replacement therapy)을 시행하 는 것이 유리하다. 단, 신속한 교정이 필요하므로 복막투 석은 적절하지 않다. 투석으로 제거될 수 있는 항암제(시 클로포스파미드)는 투석 직후에 투여해야 한다. 급성기에 는 급격한 종양세포 파괴 속도를 고려하여 12 시간마다 투 석을 시행할 수 있다.

\section{References}

1. Howard SC, Jones DP, Pui CH. The tumor lysis syndrome. N Engl J Med 2011;364:1844-54.

2. Coiffier B, Altman A, Pui CH, Younes A, Cairo MS. Guidelines for the management of pediatric and adult tumor lysis syndrome: an evidence-based review. J Clin Oncol 2008;26:2767-78

3. Montesinos P, Lorenzo I, Martín G, Sanz J, Pérez-Sirvent ML, Martínez D, et al. Tumor lysis syndrome in patients with acute myeloid leukemia: identification of risk factors and development of a predictive model. Haematologica 2008;93:67-74.

4. Cairo MS, Coiffier B, Reiter A, Younes A; TLS Expert Panel. Recommendations for the evaluation of risk and prophylaxis of tumour lysis syndrome (TLS) in adults and children with malignant diseases: an expert TLS panel consensus. Br J Haematol 2010;149:578-86.

5. Conger JD, Falk SA. Intrarenal dynamics in the pathogenesis and prophylaxis of acute uric acid nephropathy. J Clin Invest 1977;59:786-93.

6. McLeod HL. Clinically relevant drug-drug interactions in oncology. Br J Clin Pharmacol 1998;45:539-44.

7. Bertrand Y, Mechinaud F, Brethon B, Mialou V, Auvrignon A, Nelken B, et al. SFCE (Société Française de Lutte contre les Cancers et Leucémies de l'Enfant et de l'Adolescent) recommendations for the management of tumor lysis syndrome (TLS) with rasburicase: an observational

\section{결 론}

종양용해증후군은 암 환자에서 고요산혈증, 고칼륨혈 증, 고인산혈증, 저칼슘혈증과 신부전을 특징으로 하는 종 양학적 응급으로, 특히 종양세포의 성장속도가 빠르고 화 학요법에 민감한 혈액암에서 자주 발생한다. 종양용해증 후군에 따른 신부전은 지지요법과 신대체요법을 통해 치 료할 수 있다. 따라서, 종양용해증후군 발생 여부에 대해 세심하게 관찰함으로써 적절한 예방요법, 조속한 진단, 적 극적인 치료를 시행해야 한다.

survey. J Pediatr Hematol Oncol 2008;30:267-71.

8. Goldman SC, Holcenberg JS, Finklestein JZ, Hutchinson R, Kreissman S, Johnson FL, et al. A randomized comparison between rasburicase and allopurinol in children with lymphoma or leukemia at high risk for tumor lysis. Blood 2001;97:2998-3003.

9. Cheuk DK, Chiang AK, Chan GC, Ha SY. Urate oxidase for the prevention and treatment of tumour lysis syndrome in children with cancer. Cochrane Database Syst Rev 2014;14:CD006945.

10. Annemans L, Moeremans K, Lamotte M, Garcia Conde J, van den Berg H, Myint $\mathrm{H}$, et al. Pan-European multicentre economic evaluation of recombinant uric acid oxidase (rasburicase) in prophylaxis and treatment of hyperuricaemia and tumour lysis syndrome in haematological cancer patients. Support Care Cancer 2003;11:249-57.

11. Relling MV, McDonagh EM, Chang T, Caudle KE, McLeod HL, Haidar CE, et al. Clinical Pharmacogenetics Implementation Consortium (CPIC) guidelines for rasburicase therapy in the context of G6PD deficiency genotype. Clin Pharmacol Ther 2014;96:169-74.

12. Darmon M, Guichard I, Vincent F, Schlemmer B, Azoulay E. Prognostic significance of acute renal injury in acute tumor lysis syndrome. Leuk Lymphoma 2010;51: 221-7. 